\title{
PRELIMINARY ANALYSIS OF THE PALIC LUDAS CATCHMENT
}

\section{A PALICS-LUDAS TAVAK VÍZGYŰJTŐ TERÜLETÉNEK ELŐZETES ELEMZÉSE}

\author{
HORVAT Mirjana; HORVAT Zoltan; KOCH Dániel; MAJER Fruzsina \\ (ORCID: 0000-0002-7700-024X); (ORCID: 0000-0002-4605-099X); \\ (ORCID: 0000-0002-0944-1828);(ORCID: 0000-0002-2835-2791) \\ isicm@gf.uns.ac.rs; horvatz@gf.uns.ac.rs; koch.daniel07@gmail.com; \\ majer.fruzsina@gmail.com;
}

\begin{abstract}
This paper presents the results of a preliminary analysis of Palic-Ludas catchment area near the town of Subotica in Serbia. With the aim of improving environmental situation of the considered catchment, the authors started by conducting a detailed investigation of the current situation of this area. The examination focused on obtaining and evaluating existing data in order to derive some conclusion about the present ecological, hydraulic conditions status of this catchment. This paper offers a description of the important water bodies on Palic-Ludas catchment, while including the most influential hydraulic structures. After evaluating the gathered data, a basic water budget model of Palic-Ludas lake system was constructed. The model included all the main water budget elements, the outflow from the sewage treatment plant into Lake Palic, precipitation, evaporation as well as the ground water interflow. After conducting a one year water budget simulation, the results were assessed and the influence of each component of the water budget was examined.
\end{abstract}

Keywords: Palic Ludas catchment, hydraulic and water quality data, numerical model, water budget

\begin{abstract}
Absztrakt
Ez a cikk bemutatja a Palics-Ludas tavak vízgyüjtő területén végbement előzetes felmérést, amely Szabadka város környékén helyezkedik el, Szerbiában. A vízgyüitő területen fennálló jelenlegi helyzet javítása érdekében a szerzők készítettek egy részletes elemzést. Ennek az elemzésnek az volt a célja, hogy a már létező adathalmaz segitségével hidrológiai, hidraulikai illetve vízminőségi értékelést állitson elö. A cikkben részletes leírás található a vízgyüitő területen elhelyezkedő viztestekröl, illetve ezeket hidraulikai összefüggésbe kötő mütárgyakról. Az összegyüjtött adatok értékelését követően egy vízháztartási modell lett felállitva a PalicsLudas tórendszerre. Az emlitett modell magába foglalja az összes számottevő vízmérleg elemet, a szennyvíztisztítóból származó vízhozamot, a csapadék mennyiséget, a párolgást, illetve a talajvízböl beszivárgott vízmennyiséget. A cikkben bemutatott vízmérleg modell egy éves időszakot szimulált, melynek eredményei részletes kiértékelésre kerültek.
\end{abstract}

Kulcsszavak: Palics Ludas vízgyüjtö terület, hidraulikai és vízminőségi adatok, numerikus model, vízmérleg 


\section{INTRODUCTION}

Palic-Ludas catchment is a transboundary catchment area spreading over the Serbian and Hungarian border. The main part of this area is located on the Serbian side, near the town of Subotica. The most important water bodies on this catchment are Lake Palic with the total surface area of ca. 590 ha, Lake Ludas (hence the referencing to it as the Palic-Ludas catchment) with the total surface area of ca. 358 ha, Lake Omladinsko with total surface area of ca. 13 ha, and the Palic-Ludas channel connecting the lakes Palic and Omladinsko to the Ludas that is approximately $4.5 \mathrm{~km}$ long and has a trapezoidal cross-section [1,2]. Within this channel there is a broad crested weir with over a $1.41 \mathrm{~m}$ drop in bed elevation. With the final goal of improving the environmental situation of Palic-Ludas catchment, a thorough examination was conducted on the chosen area.

This paper focuses on the preparatory works conducted on this catchment in order to allow a better insight into the current situation. After gathering and carefully examining the attained data, a basic water budget model was developed. The intention was to determine how certain segments of the system affect the response of the complete system. This was necessary to give us some insight on the direction our further work should proceed.

\section{OVERVIEW OF THE CONSIDERED AREA AND THE EXISTING DATA}

\section{Introducing Palic-Ludas catchment}

The first step was collecting the existing information regarding the Serbian part of the considered catchment. These included previous researches of other authors conducted on this area, old design projects of hydraulic structures, as well as multiple exploratory field surveys in order to acquire in situ information. Figure 1 depicts the fundamental information concerning the researched catchment.

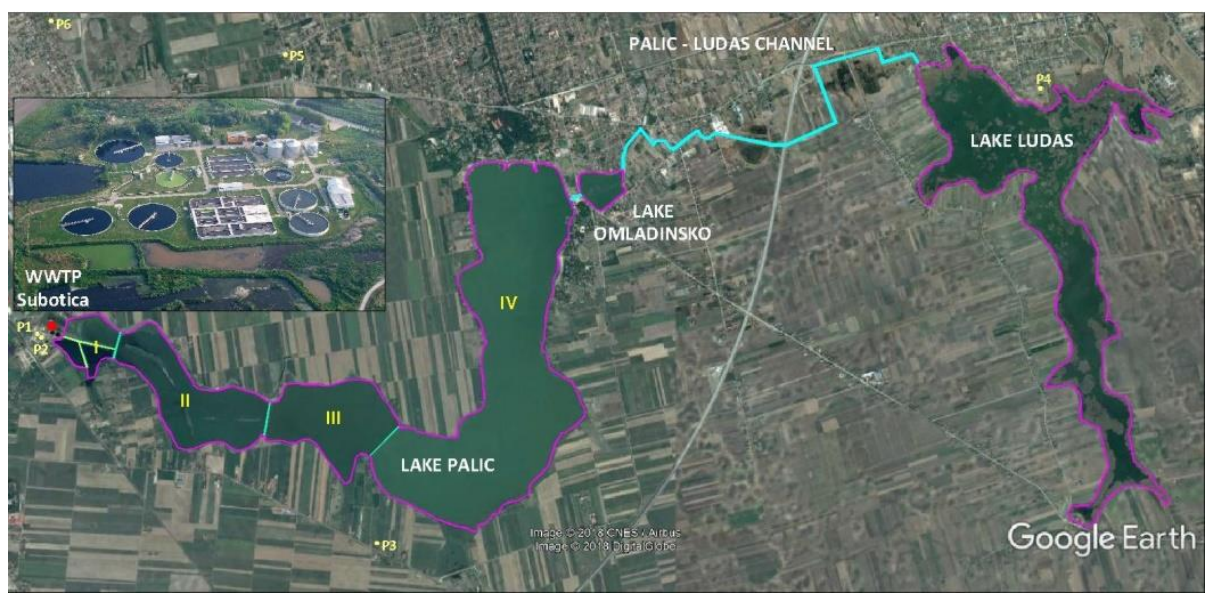

Figure 1. Map of the most important water bodies on the Palic-Ludas catchment

The primary inflow of surface water into Lake Palic is the outlet of the Wastewater Treatment Plant Subotica (WWTP), presented on Fig. 1. The treated wastewater enters the first Lagoon through the outlet of the WWTP Subotica, following which the water flows into the second Lagoon through a rectangular opening. The water from the second Lagoon can flow two ways through a ,Y" shape culvert, to the third Lagoon or to the second Sector. The second and third Sector of Lake Palic are also provided through a culvert. Following is the third Sector from which water enters the fourth and last Sector of Lake Palic via a structure consisted of one gate and a weir. 
Ultimately, the water exits Lake Palic via one underground pipe that connects it with the Omladinsko Lake. The outflow from Lake Omladinsko is accommodated by a broad crested weir, after which the water flows through a pipe entering the channel connecting Lake Omladinsko with Lake Ludas, [3,4]. Finally, the water leaves Lake Ludas over a weir. It should be mentioned that Lake Ludas is fed with the water coming from the Palic-Ludas channel and through the Kires channel.

\section{Evaluation of the gathered data}

The development of a comprehensive model requires a set of hydraulic and water quality parameters. The logical procedure is to first collect all the available data that is needed for the model development and after its careful evaluation to complement this data with the missing information by conducting measurements $[5,6]$.

Therefore, the authors first contacted the Public Utility Company "Waterworks \& Sewerage" Subotica which as a part of the regular management process conducts daily measurements of the parameters essential for them. The measured parameters that are of interest for the purpose of this work are: biological oxygen demand (BOD5), chemical oxygen demand (COD), total nitrogen, ammonium, nitrate, total phosphorous, orthophosphate, suspended solids and the total outflow from the WWTP (the inflow into the Palic Lake).

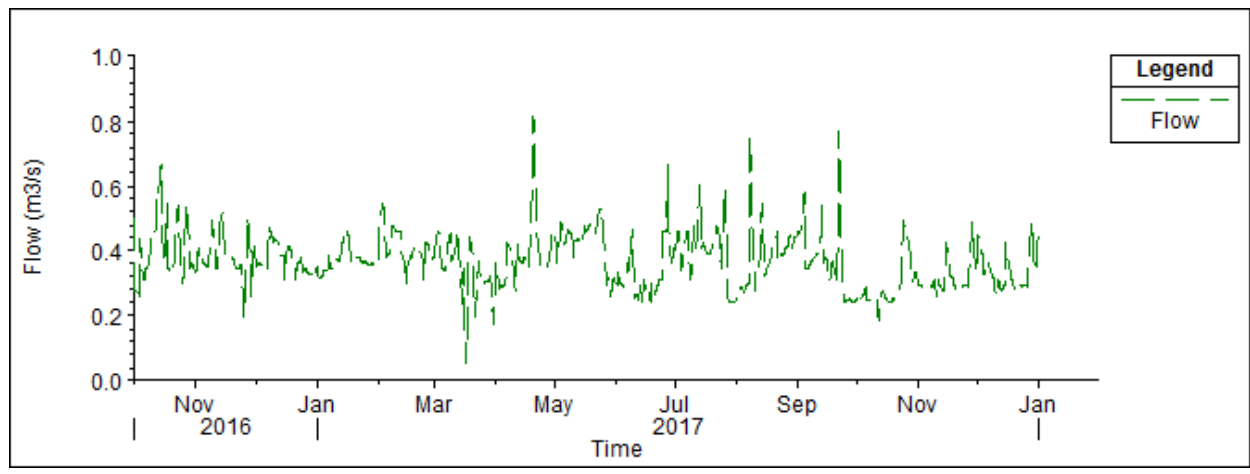

Figure 2. Hydrograph from the WWTP

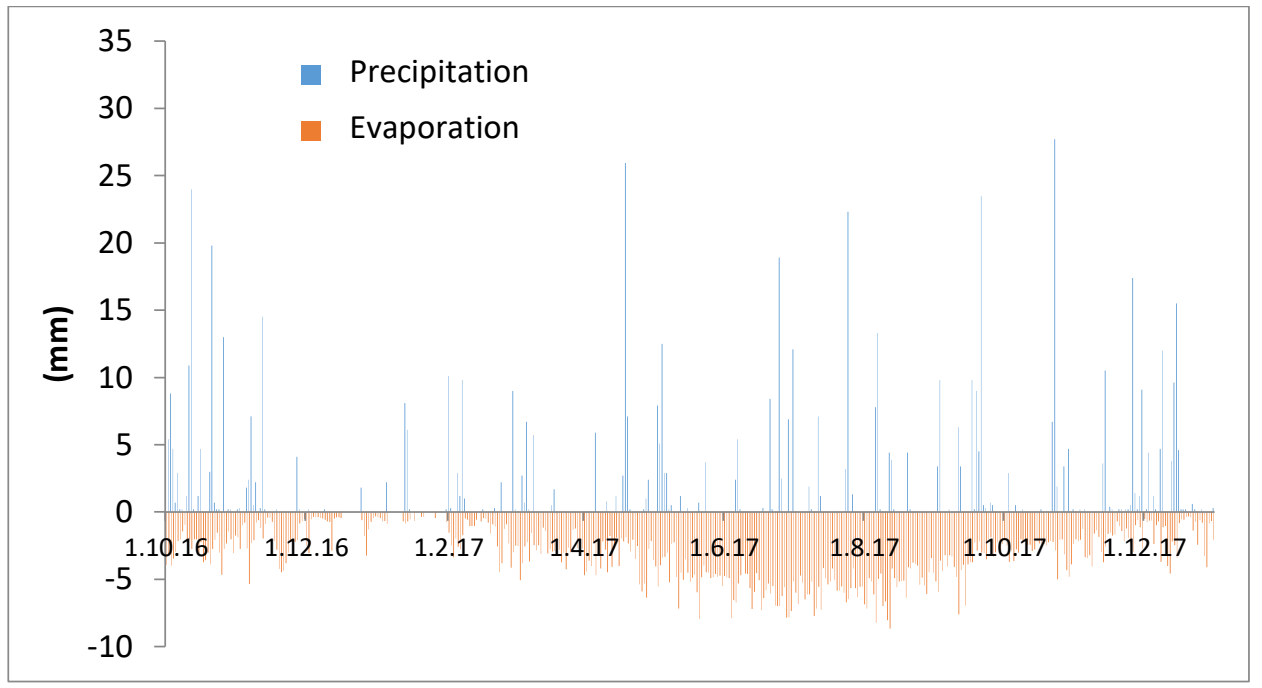

Figure 3. Measured precipitation and computed evaporation

The outflow hydrograph from the WWTP into the first Lagoon for the time interval between October $1^{\text {st }} 2016$ and December $31^{\text {st }}$ of 2017 is presented on Fig. 2. It is self-evident that the approximate outflow from the WWTP is around $0.4 \mathrm{~m}^{3} / \mathrm{s}$, with some deviations that are a consequence of heavy rains. 


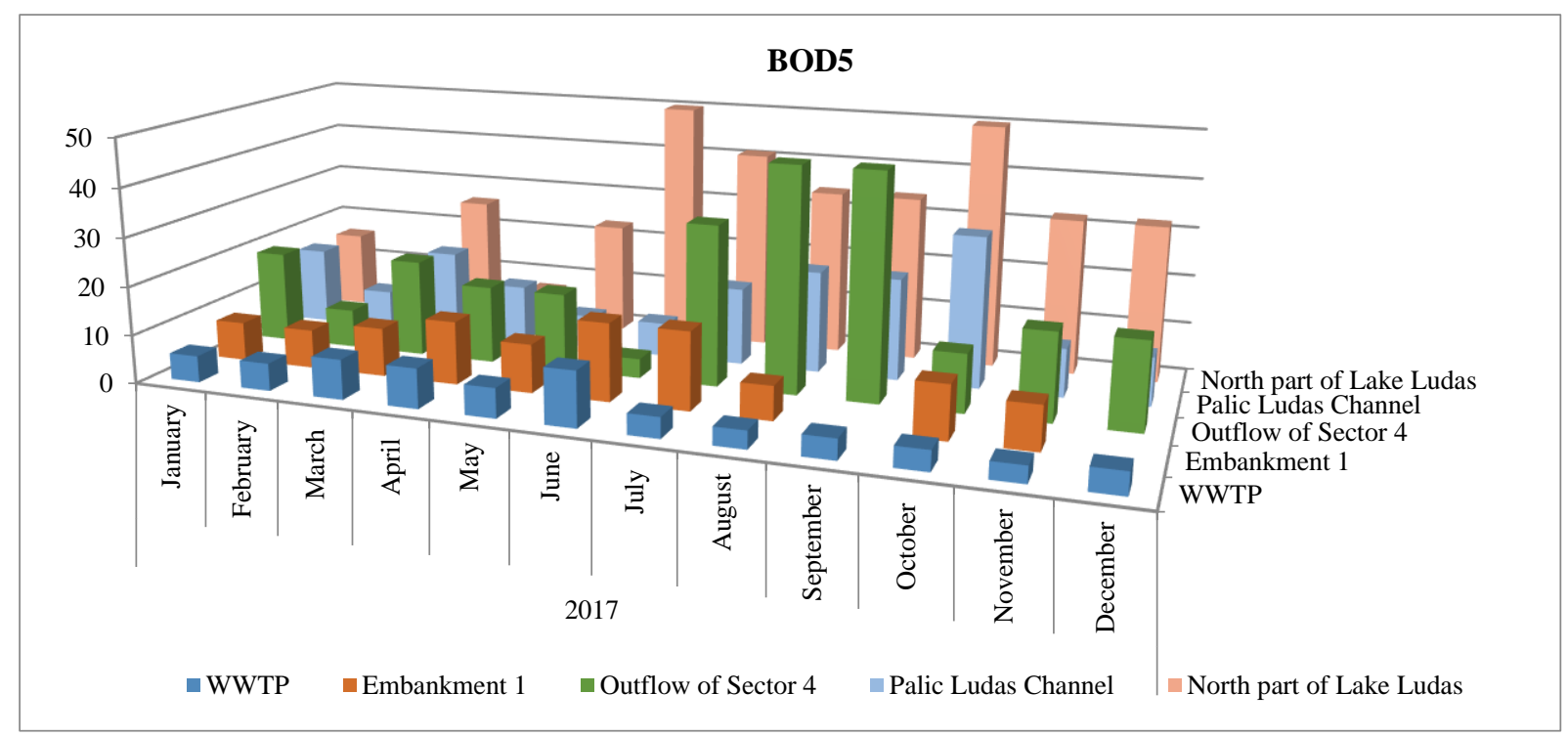

Figure 4. Measured $\mathrm{BOD}_{5}$ values

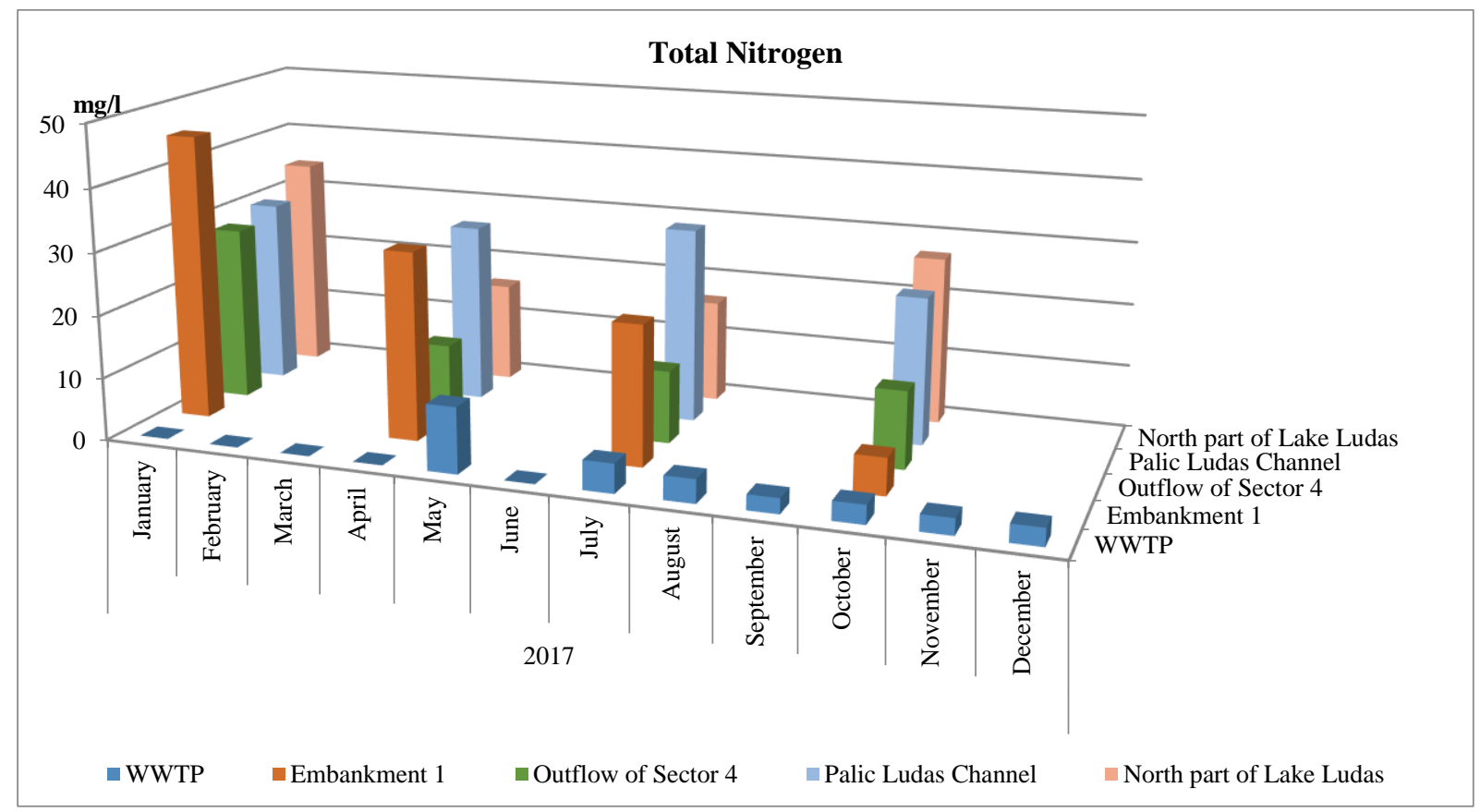

Figure 5. Measured Total Nitrogen values for 2017

The precipitation values were measured for the considered period, and are shown on Fig. 3. Using also measured values of temperature and the speed of wind made it possible for us to compute the evaporation for the studied time interval, presented on Fig. 3.

Furthermore, the City of Subotica systematically publishes measurements conducted by the Public Health Institute in Subotica. These measurements are done in all four Sectors of Lake Palic, as follows: along the first, second and third levee, in the middle of the fourth Sector and at the Lake Palic's outflow. Data is also gathered in the Palic-Ludas channel, and in Lake Ludas on its north part near the inflow, in the middle and on the south of the lake. These measurements are officially carried out every month and include a wide set of physical, chemical and biological parameters. For this phase of our research we analyzed the following: BOD $5, \mathrm{COD}_{\text {, }}$ total phosphorous, orthophosphate, total nitrogen, ammonium nitrogen, nitrate-nitrogen and suspended solids. Some of the results are presented on the following figures. 
Figures 4, 5, 6, 7, and 8 represent the water quality measurements for the year 2017, at the outflow of the WWTP, Embankment 1 (which separates the first two Sectors of Lake Palic), outflow of the fourth Sector, the Palic-Ludas channel and on the Northern part of Lake Ludas. The parameters depicted are $\mathrm{BOD}_{5}$, Total Nitrogen, Ammonium Nitrogen, Nitrate-Nitrogen and Total Phosphorus.

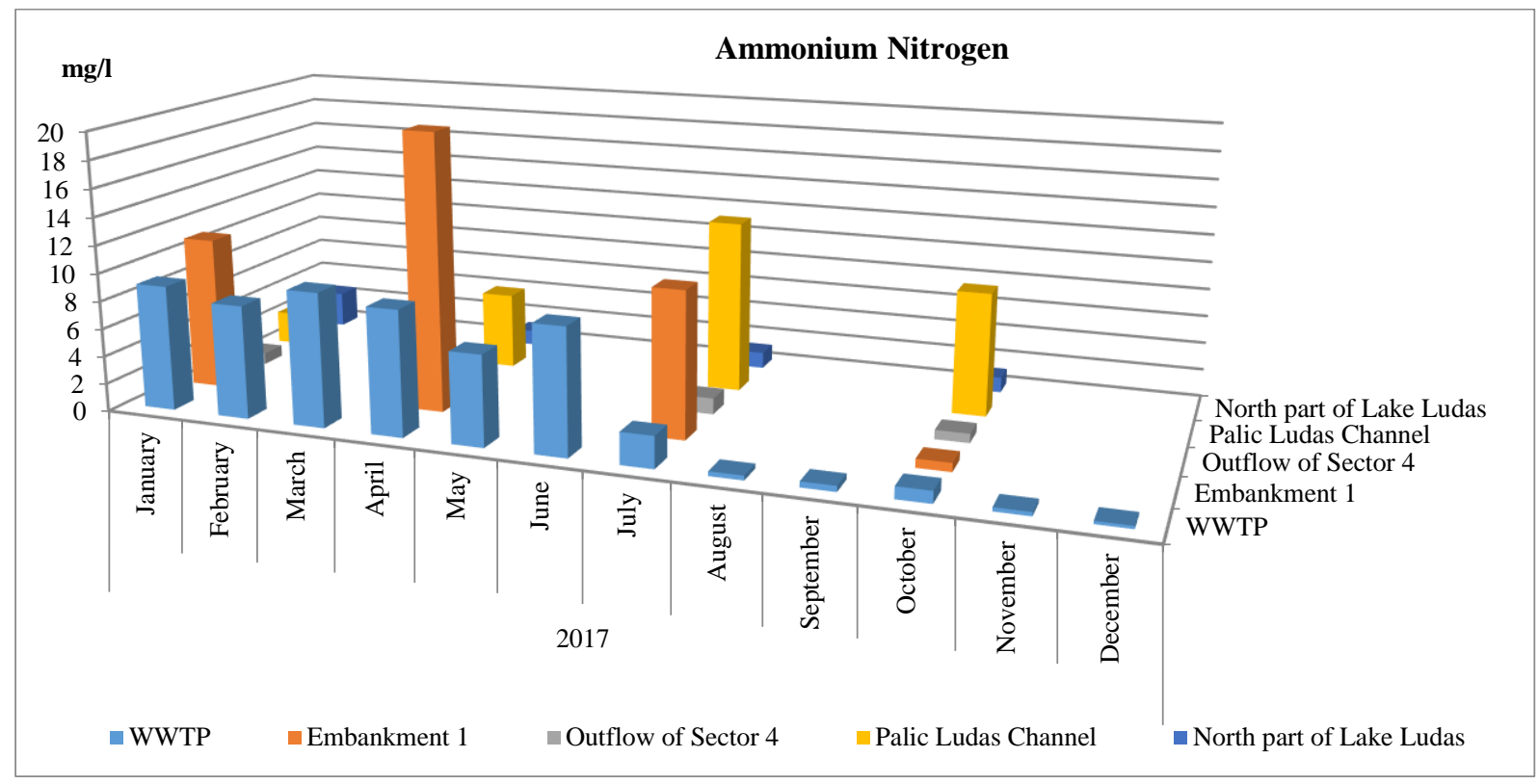

Figure 6. Measured Ammonium Nitrogen values for 2017

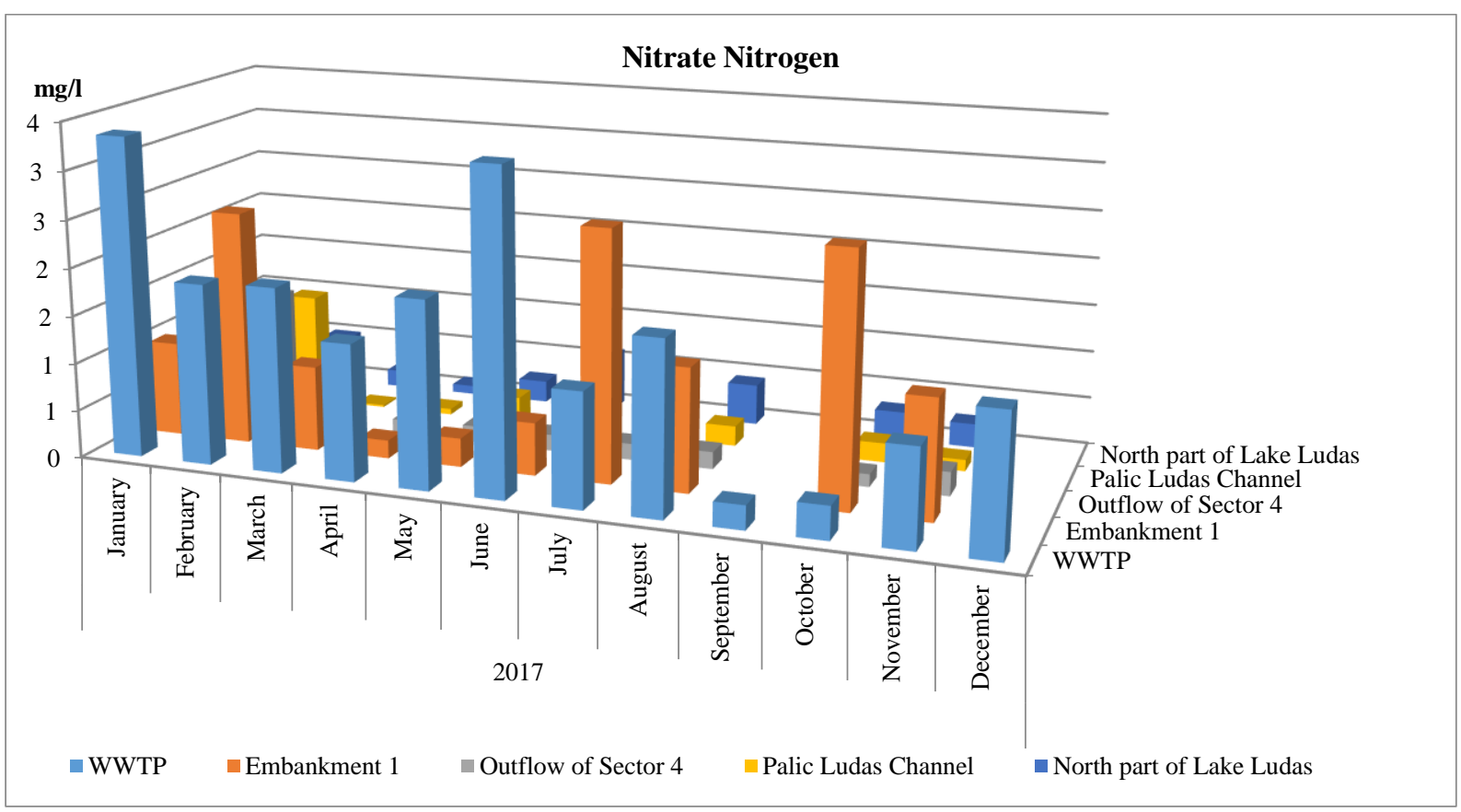

Figure 7. Measured Nitrate Nitrogen for 2017

Figure 4 shows the values of $\mathrm{BOD}_{5}$ through space and time. By evaluating the presented results carefully, it can be concluded that there is a tendency of increasing $\mathrm{BOD}_{5}$ towards the outflow of the system, implying a possible contaminant source within the system.

Further analysis of the displayed results will bring some confusion to the researcher, since no obvious conclusions can be derived. Although, a few tendencies can be identified on these 
charts (e.g. in January there was a high concentration of total nitrogen in the whole system) there can be no significant conclusion regarding the water quality changes in the system during the year. If nitrate-nitrogen, ammonium-nitrogen are subtracted from total nitrogen, organic nitrogen could be determined and that could reveal the differences of solid transport among the regions.

One of the reasons for this is that complete measurements are available only for January, April, July, and October. The rest of the year, measurements of some of the parameters were completely omitted, while others were measured on some parts of the system (that is why the results are only presented in five points). Consequently, it is impossible to draw a reliable conclusion.

In order to draw reliable conclusions, a more comprehensive set of measurements needs to be carried out regarding the water quality. This would help answering questions as: Is it possible to identify a recurring tendency? How does the WWTP affect the lakes? How fast does the lake system react to the inflow? What is the influence of the groundwater and precipitation influence the water quality?

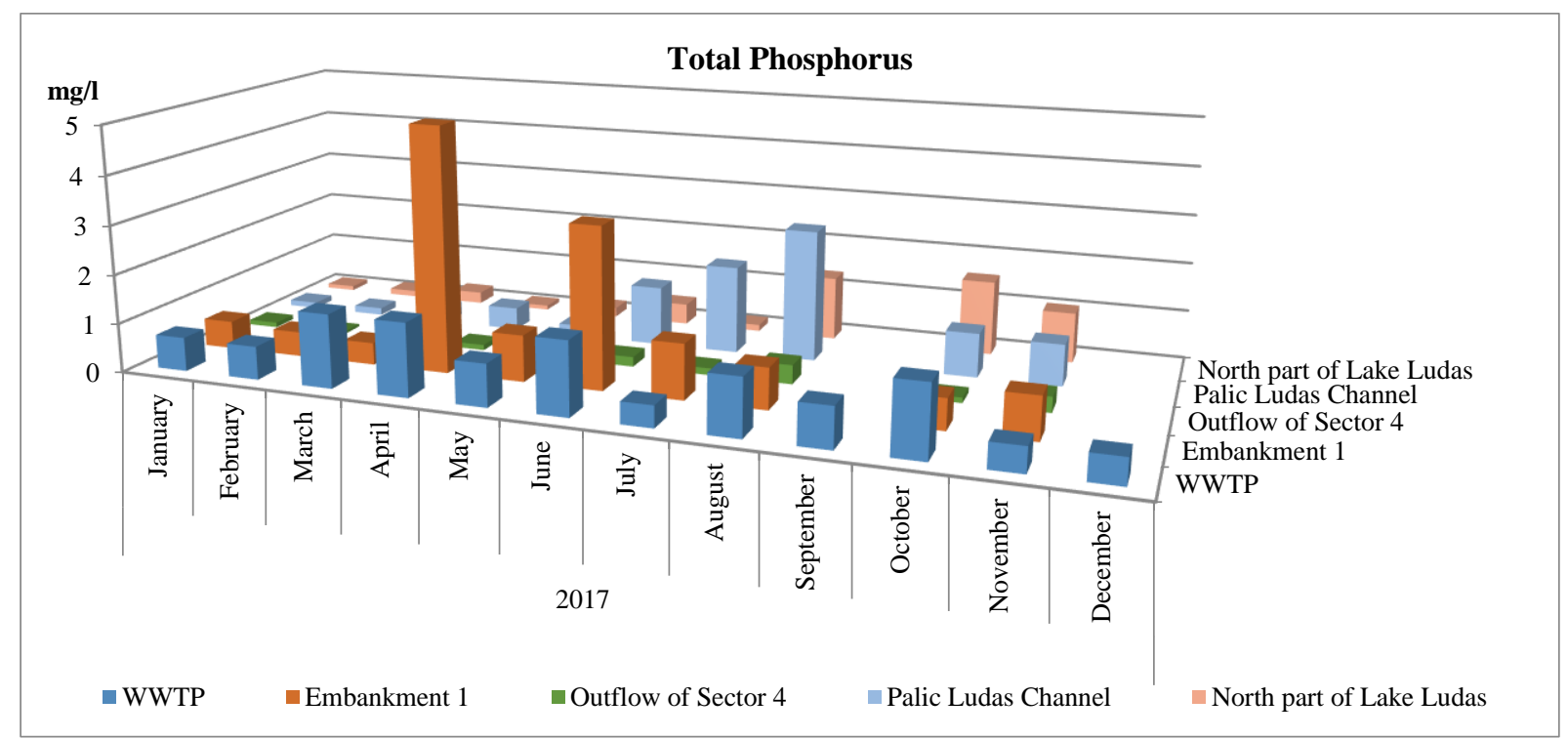

Figure 8. Measured Total Phosphorus values for 2017

\section{DEVELOPMENT OF WATER BUDGET MODEL}

As it was previously stated, the main water bodies on the researched catchment are three lakes: Lake Palic Lake Omladinsko and Lake Ludas. The representation of these lakes in the prepared model is given on Figure 9.

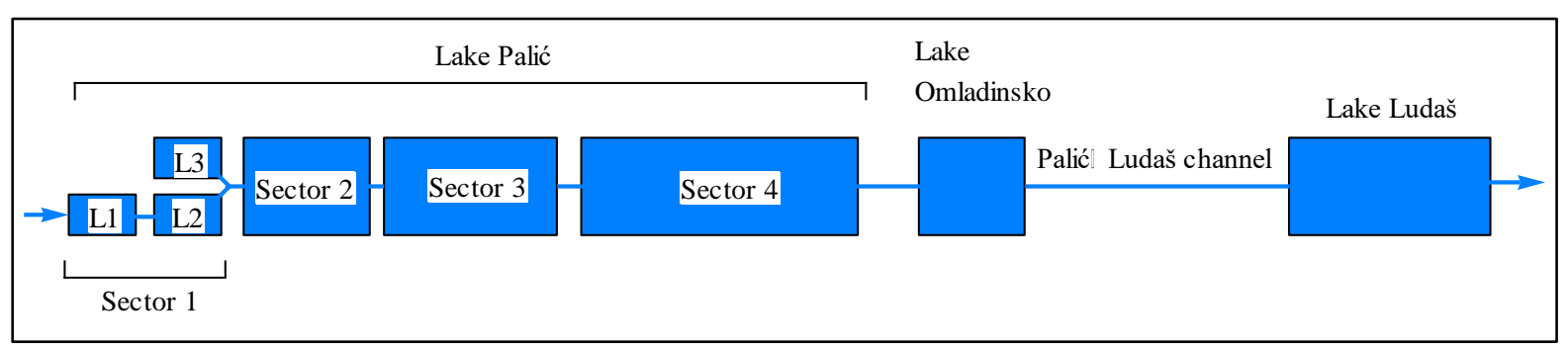

Figure 9. The schematic representation of the modeled system

The Lagoons and Sections within Lake Palic, and Lake Palic with Lake Omladinsko are connected throughout culverts of different dimensions and cross-sections, as mentioned earlier. 
The main source of surface water inflow in the system is the outflow from the WWTP, that releases the treated water into the first Lagoon. Aside from the inflow coming from the WWTP, the other influential water budget components are the precipitation, evaporation and the groundwater.

The numerical model is constructed as a series of storage areas [7] representing a specific Lagoon, Sector or Lake of the system. The changes in water elevation in these storage areas are determined by balancing the continuity equation for each of them. The connection of the storage areas is facilitated either by hydraulic structures with defined rating curves or with a channel. When conducting the hydraulic computation in the channels, the model solves the St. Venant equations. We could have determined the water quantity and water level at several points. The precipitation and evaporation are taken into account only for the storage areas, while neglecting their influence on the hydraulic computation of the channel [8]. On the other hand, the influence of the groundwater interflow is included for both the storage areas, as well as for the channels.

Keeping in mind the unsteady inflow entering the modeled system from the WWTP and the varying values of precipitation and evaporation throughout the year, the computations are performed as an unsteady flow scenario. For the stabilization period, the authors selected three months, October, November and December of the year 2016. Consequently, the whole simulation lasted from October the $1^{\text {st }}$ of 2016 until December $31^{\text {st }}$ of 2017.

The main input data is the hydrograph, shown on Fig. 2, that represents the outflow from the WWTP and the inflow into the Lake Palic via its first Lagoon. The peaks on the hydrograph result from high precipitations on the catchment that are drained through the sewage system that eventually end up in the WWTP. As stated before, the precipitation input values are measured values, whereas the evaporation values are determined by computation using measured temperatures and wind speeds in the modeled area. It should be stated that due to the fact that the evaporation is not directly measured, one should recognize the possibility that these computed values can deviate from real ones.

Input data for the groundwater part of the system was taken as the average value from historical records. Although, this means that the groundwater elevations are constant during the simulated time period, they represent real (measured) values in the modeled area. This is one of the areas where not enough data was found, that will be later complemented with systematic measurements as a result of this research.

\section{Results of the water budget model}

Within this research, the authors carried out three sets of numerical simulations. The first scenario has the goal of reproducing the situation encountered on the preliminary field survey and is based on real data including all of the key water budget elements.

The second scenario has the purpose to investigate the influence of groundwater interflow. This is accomplished by conducting a simulation where the groundwater is excluded, therefore allowing the authors to gain some insight into its effect on the considered system.

The final scenario introduces a theoretical situation, hereby investigating the consequences for the possibility that the water from the WWTP does not enter the Lake Palic, but bypasses the complete lake system.

As already mentioned, the first simulation aims to reproduce hydraulic variables of the considered area during the simulated time. Figure 10 shows the water surface and net inflow of the third Sector of Lake Palic, where no significant changes can be observed.

Figure 11. depicts the water surface elevation and net inflow for the fourth Sector of the Palic Lake. There are no significant changes in the water levels. The only significant variation in water levels is between the third Sector, with the water level of ca. $102.8 \mathrm{~m}$, and the fourth Sector with water level of $101.55 \mathrm{~m}$. This is the result of the weir placed between these two sectors. 


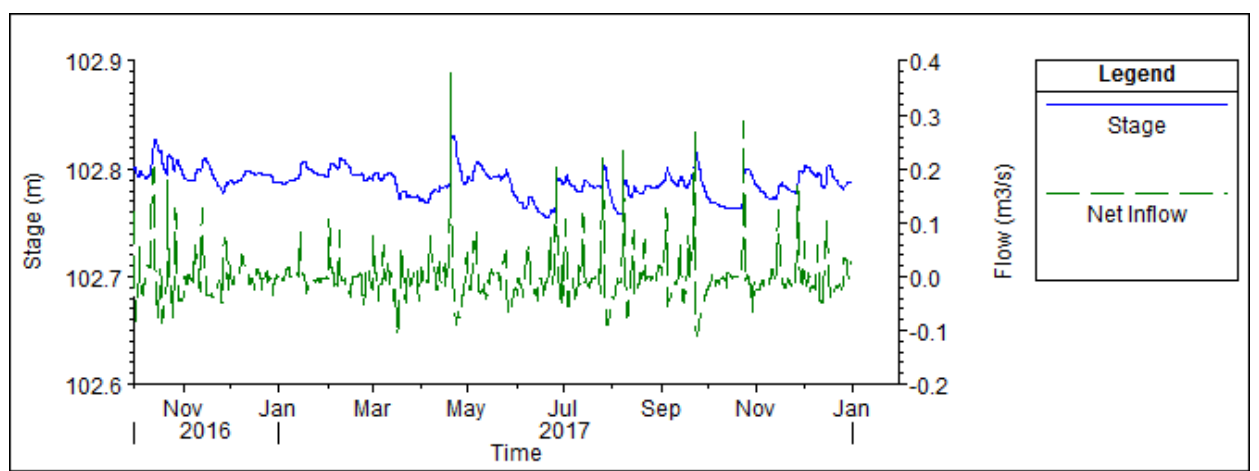

Figure 10. Water surface elevation and net inflow for the third Sector

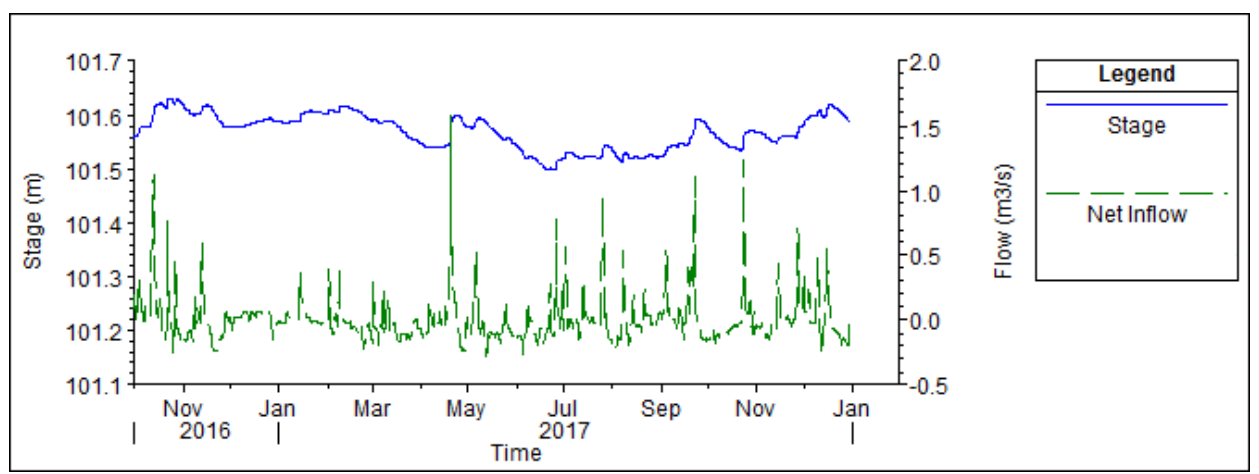

Figure 11. Water surface elevation and net inflow for the fourth Sector

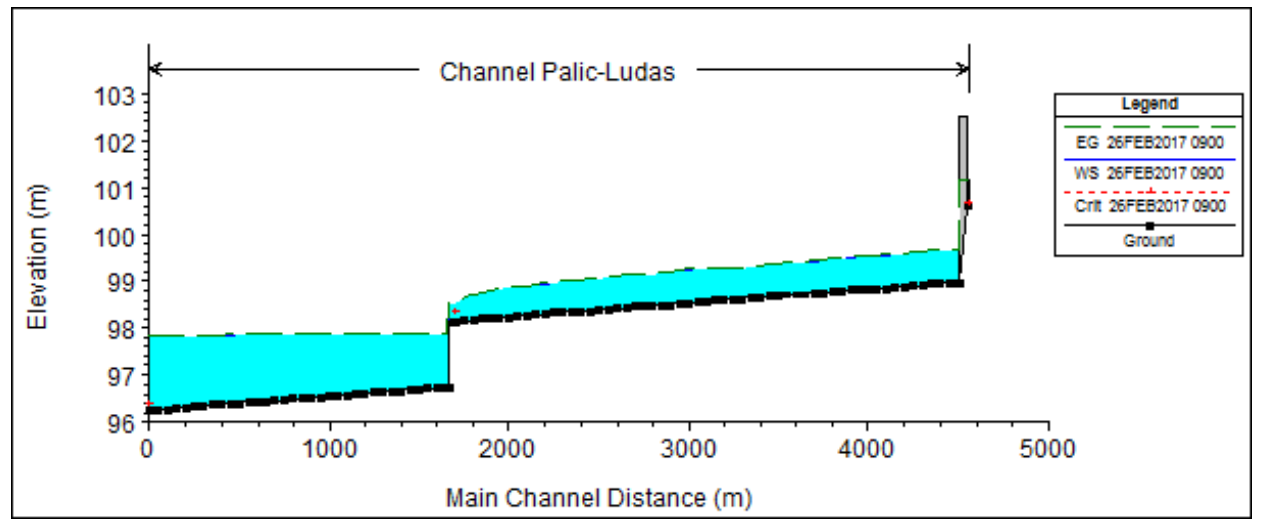

Figure 12. Water surface elevation in the Palic-Ludas channel

Figure 12. presents the profile of the Palic-Ludas channel for the $26^{\text {th }}$ of February, year 2017. The backwater effect of Lake Ludas can be observed on the part of the channel, from RKM $0+000$ to $1+650$. The upstream part of the same channel, from RKM $1+700$ to $4+500$, is governed by the broad crested weir and the drop in bed elevation at RKM 1+670.

Figure 13. demonstrates the inflow into Lake Ludas resulting from the Palic-Ludas channel. Although the inflow into the system, resulting from the WWTP and groundwater is approximately uniform during the year, the discharge into Lake Ludas shows a significant drop in summer, from June to August. This can be explained as a consequence of more intense evaporation during the summer time in Lake Palic and Lake Omladinsko. 


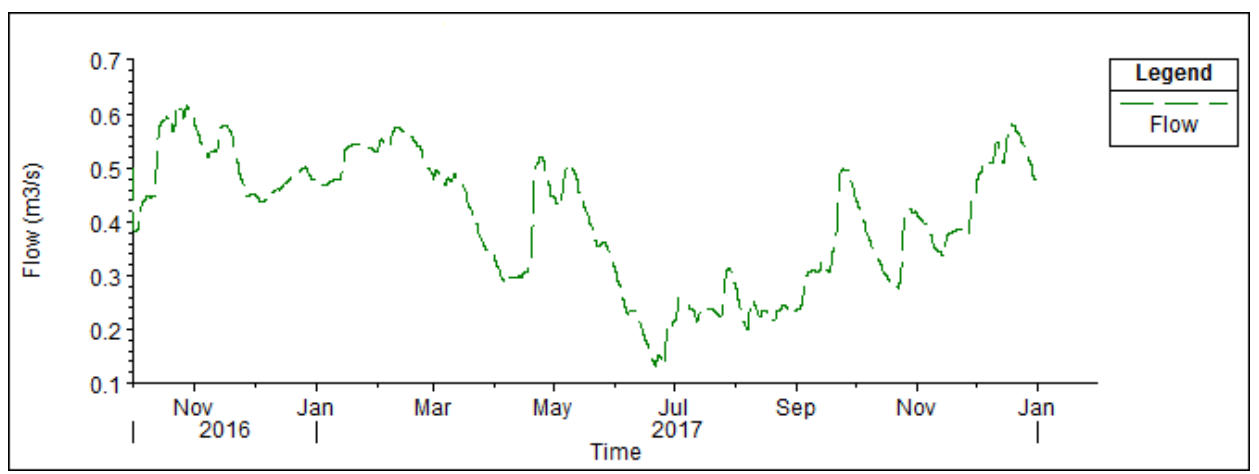

Figure 13. Inflow into Lake Ludas from the Palic-Ludas channel

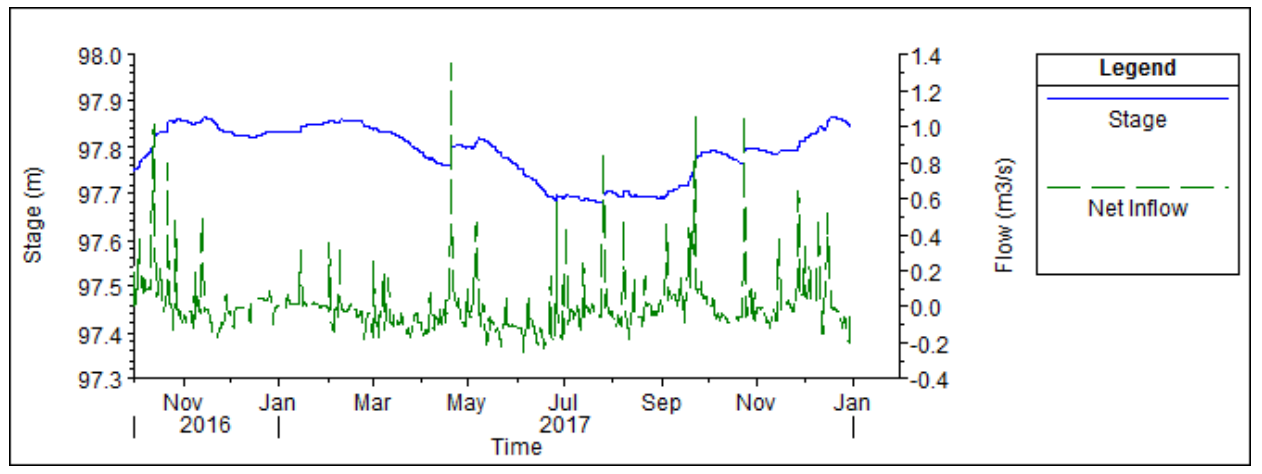

Figure 14. Water surface elevation and net inflow for Lake Ludas

Figure 14. represents the water surface elevation and the net inflow into Lake Ludas. Here the results show a distinct drop of water surface elevation of approximately $10 \mathrm{~cm}$ during the summer. This occurrence in to be expected, but nevertheless should be confirmed by future field observations.

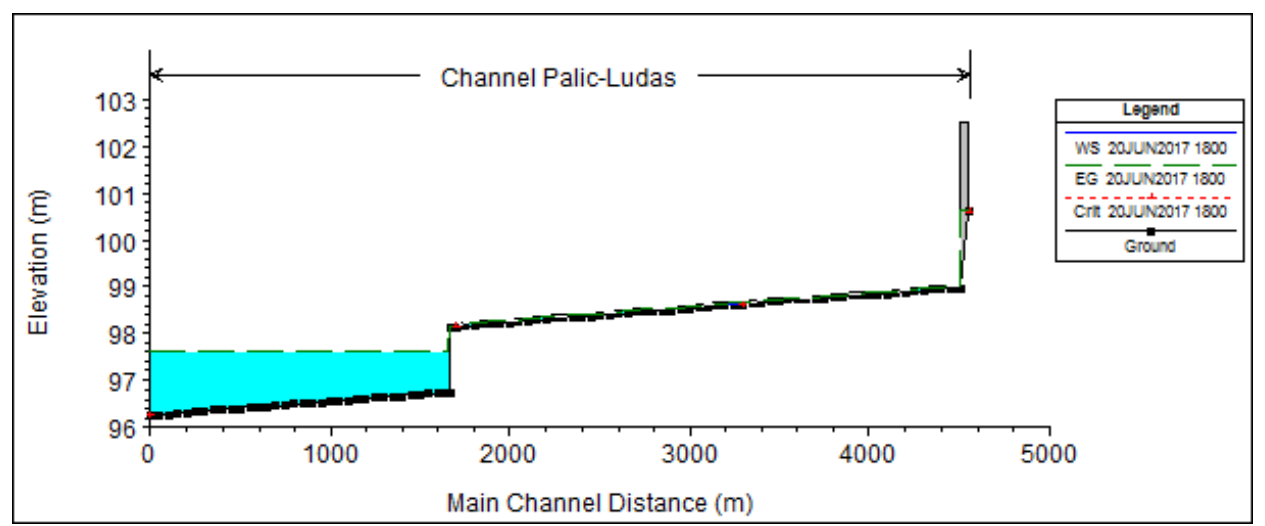

Figure 15. Water surface elevation in the Palic-Ludas channel with no groundwater interflow with the system

The second set of numerical tests aimed to estimate the importance of groundwater interflow within the modeled system. In order to do so, the groundwater was excluded from the model, thus conducting the simulations with the remaining elements of the water budget. The most compelling result is presented on Fig. 15. The absence of groundwater feeding the lakes would result in the drying up of the Palic-Ludas channel in the summer. Bearing in mind that this phenomenon does not occur, it can be concluded that the groundwater flow into the system is noteworthy part of the water budget that cannot be neglected. 


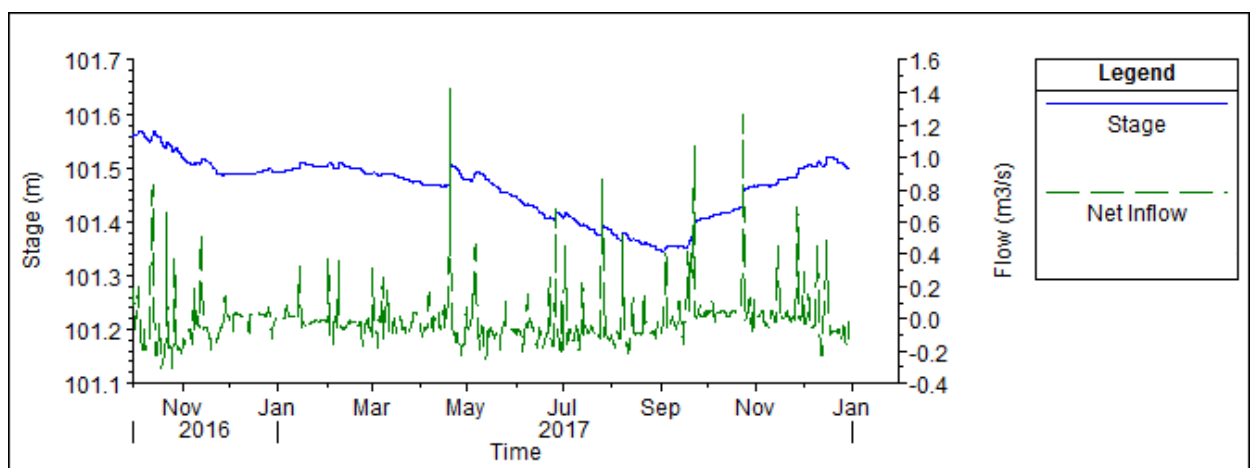

Figure 16. Water surface elevation and net inflow for the fourth Sector without inflow from the WWTP

The last set of simulations were investigating the scenario if the WWTP outflow would be rerouted bypassing the complete lake system. Without the inflow from the WWTP there would be a drop of water elevation of approximately $0.2 \mathrm{~m}$ (ca. 10\%) in the fourth Sector, Fig. 16, and $0.45 \mathrm{~m}$ in Lake Ludas (25\%), Fig. 17. This would have a damaging effect on Lake Ludas, since the flow of water in the Palic-Ludas channel would completely seas in the summer, as shown on Fig. 18.

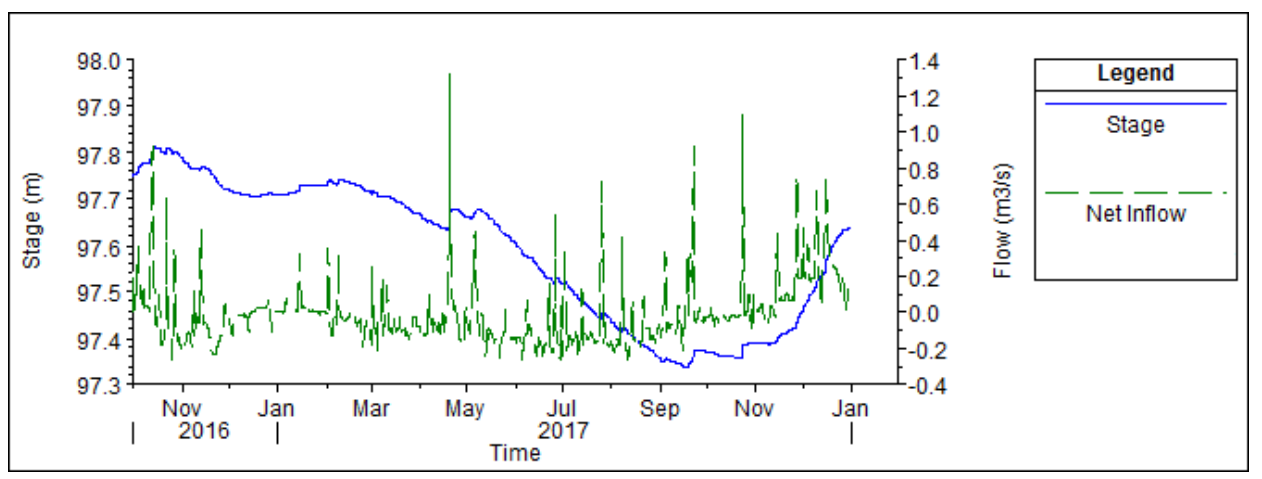

Figure 17. Water surface elevation and net inflow for Lake Ludas without inflow from the WWTP

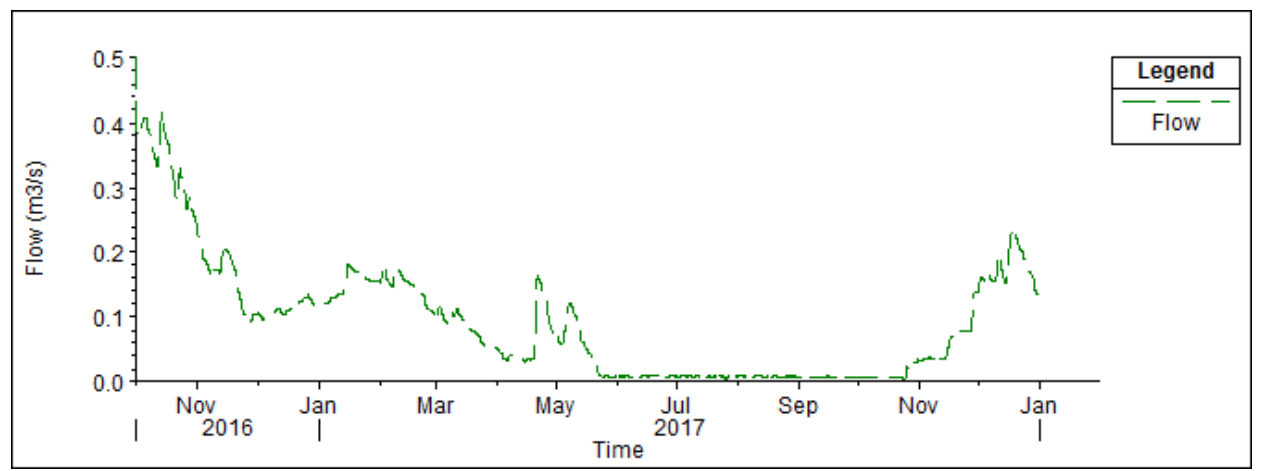

Figure 18. Flow into Lake Ludas without inflow from the WWTP

\section{CONCLUSIONS}

The evaluated Palic-Ludas catchment includes a fairly complex system of water bodies and channels. Coming to some kind of guidance for the improvement of the catchment's environmental aspect requires the development of a water budget and water quality model. The existing data available for the purpose of the water budget model development are decent, although it would be advisable to complement the hydraulic measurements with systematic groundwater elevation measurements in appropriate locations. 
On the other hand, the water quality measurements need to be carried out with greater frequency until some kind of correlation can be established. Since the location of the measurements in the Palic-Ludas channel is unknown, the reason of increased BOD5 values is unattainable. Therefore, it would be reasonable to conduct measurements in multiple points along the channel with the goal of identifying the cause of this occurrence.

The constructed water budget model for the Palic-Ludas lake system showed that there is no significant variation of the water surface elevations in the modeled lakes, during the simulated time. Furthermore, it was shown that Lake Ludas can endure a slight decrease in water surface elevation in the summer.

After examining the results of the theoretical scenarios, the authors concluded that the groundwater interflow represents an important part of the water budget. Moreover, the possibility of the inflow from the WWTP completely bypassing the lakes should no longer be considered since this scenario would result in significant drops in water surface elevations in the fourth Sector of Lake Palic, and in the Lake Ludas. This would surely have negative consequences on the water quality as well, but this is yet to be confirmed.

\section{REFERENCES}

[1] CINKLER, R.: Glavni projekat nasipa ustave i preliva E-539/3-8, Građevinski zavod pri VTGS̆, Subotica, 1972.

[2] REZNIČEK, J.: Odvodni kanal Palić-Ludaš E-539-5, Građevinski zavod pri VTGŠ, Subotica, 1971.

[3] BOŽIĆ, M.: Čišćenje i remedijacija mulja iz jezera Palić i Ludaš, Institut za vodoprivredu "Jaroslav Černi", Beograd, 2010.

[4] HOVANJ, L.: Pregled promena u slivu Palićkog jezera od kraja XVII veka do danas $i$ istraživanje tih promena - Doktorska disertacija, Građevinski fakultet Subotica, Subotica, 2008.

[5] WU, W.: Computational River Dynamics, Taylor \& Francis Group, London, 2008.

[6] MÁTRAI, I.; VADKERTI, E.Tározók ökológiai állapotfelmérése. In: Szlávik, L.; Gampel, T.; Szigeti, E. (szerk.) A Magyar Hidrológiai Társaság, XXXIII. Országos Vándorgyülés dolgozatai, Paper: 8/6, 12 p. Budapest, 2015

[7] G. W. BRUNNER, HEC-RAS River Analysis System User's Manual Version 5.0, US Army Corps of Engineers, Hydrologic Engineering Center, February 2016

[8] KARCHES, T.; Detection of dead-zones with analysis of flow pattern in open channel flows. POLLACK PERIODICA: AN INTERNATIONAL JOURNAL FOR ENGINEERING AND INFORMATION SCIENCES 7 pp. 139-146., 8 p. 2012 